\title{
LEARNING FROM THE ABODE OF CHAOS : INSTITUTIONS, STAKEHOLDERS AND CONTEMPORARY CHALLENGES OF THE CONSERVATION DOCTRINE
}

\section{HOUBART Claudine ${ }^{1}$}

${ }^{1}$ Claudine Houbat, University of Liège (Belgium), Faculty of Architecture https://orcid.org/0000-0002-7037-5815

Ninety years after the first international conference on the conservation and restoration of the built heritage was held in Athens in an attempt to formulate some common principles ${ }^{1}$, the heritage doctrine is facing unprecedented challenges. After the continuous expansion of the heritage corpus, both tangible and intangible, has led to a multiplication of specialized doctrinal documents, the increasing involvement of users in decision-making processes and the imperatives of sustainability are challenging approaches that were, until a few years ago, the object of consensus within the restricted world of heritage experts. In this context, the principles laid down in doctrinal documents are perhaps more necessary than ever, but they are also often out of step with the needs of all actors and the contemporary society. The call for papers for the anniversary colloquium of the so-called "Athens Charter" 2 posed the following question : "Does current conservation theory strike the right balance between stakeholder rights and heritage rights"? In this paper, I will address this question through a specific and atypical case study : the Abode of Chaos.

\footnotetext{
1 Première conférence internationale pour létude des problèmes relatifs à la protection et la conservation des monuments d’art et d'histoire, Bulletin de la coopération intellectuelle, Société des Nations, 10, 1931, pp. 469-481.

2 Pierre Leveau rightly pointed out in 2017 that "this document that followed the agenda of the meeting was not a charter, but a mere record"; see Leveau P., L'Institution de la conservation du patrimoine culturel dans l'entre-deux-guerres, Dijon : Office de coopération et d'information muséales, 2017, p. 249.
} 


\section{Claudine Houbart}

\section{A living mirror of the Anthropocene}

The Abode of Chaos is a complex site located in Saint-Romain-au-Mont-d'Or, a village ten kilometers North of Lyon, France 3 . Dating back to the 17th century, the site hosts the remains of a Protestant temple as well as vernacular buildings integrated into a total work of art created since 1999 by thierry Ehrmann, an artist and businessman. The buildings as well as the site have become the support of more than 6500 artworks mostly made of recycled materials, echoing the often dark news of the last 20 years : climate change, globalized trade, exhaustion of resources, terrorism, war, intolerance, COVID 19, which are embodied there without concession, materializing in murals, inscriptions, monumental sculptures, wounds inflicted on the vernacular buildings, recycled materials and obsolete objects, diverted and reused (Fig. 1).

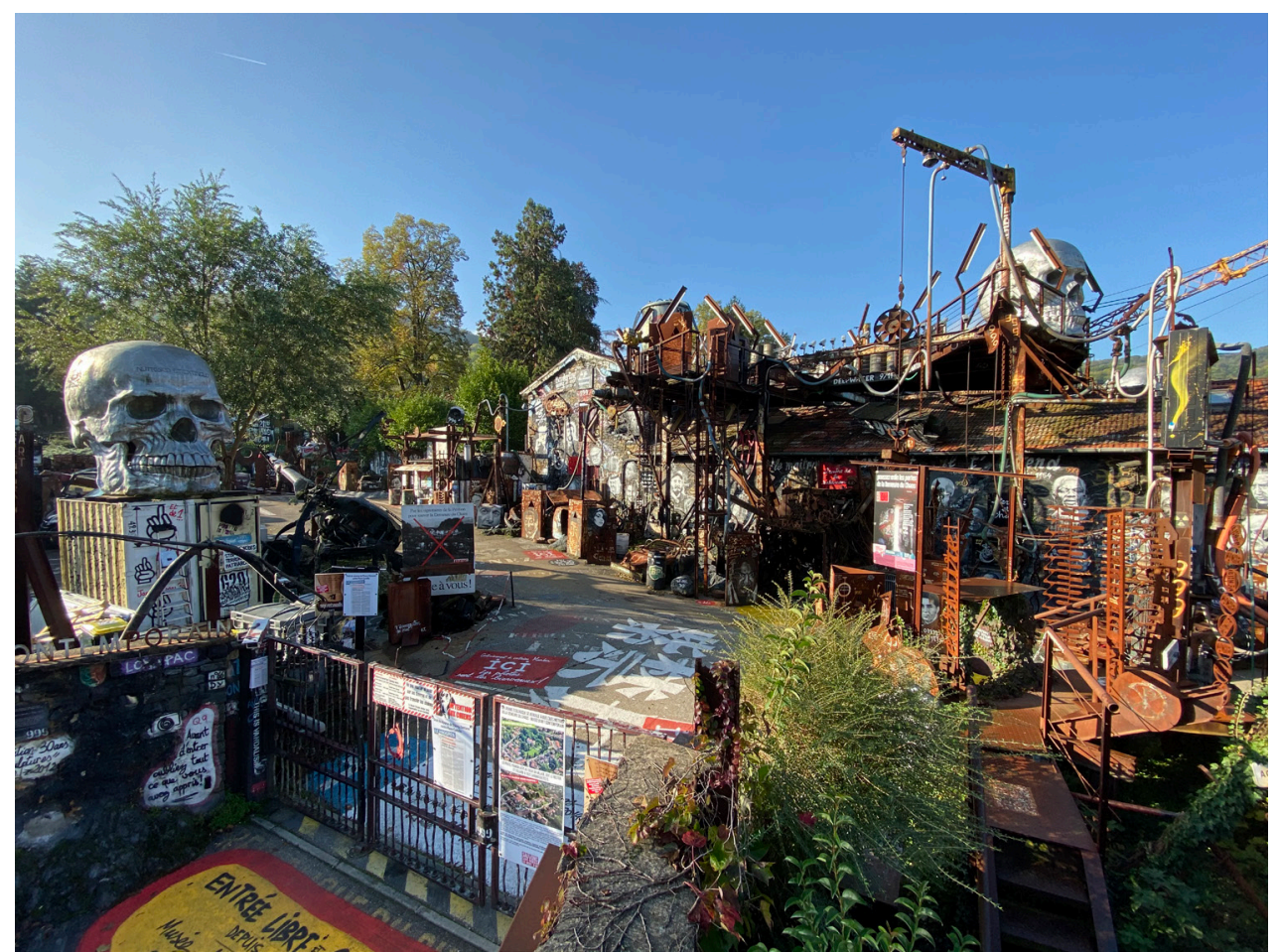

Fig.1 : Overall view of the Abode of Chaos (C) thierry Ehrmann, 26.10 .2019 ( https://www.flickr.com/ photos/home_of_chaos/48973390527/in/album-72157709676617736/)

The ongoing creative process involving the site does not fall under the classical approaches of conservation-restoration, as enshrined in doctrinal documents. In the early 1990s, when thierry Ehrmann purchased the site to establish his company's offices and residence, the complex was made up of ruined vernacular buildings on a plot of land littered with the construction debris of the surrounding residential estates. In the first instance, he restored all the buildings and cleared 
most of the site. But in 1999, his project took a radical turn: with the idea that "all that remains of the bourgeois pomp must drown in a permanent state of war", he gradually converted the buildings and grounds into a "total work of art" mirroring the contemporary world in its darkest and most disturbing aspects. Rather than resigning itself or turning a blind eye, the Abode of Chaos proposes not only facing the drifts of the world, but also seeing them as the alchemical "materia prima" of a possible future. The project became even more important after $9 / 11$, a real shock for Ehrmann, who translated the event live through a monumental sculpture.

In 2003, while clearing a remote part of the site, overgrown with brambles, to install an artwork, thierry Ehrmann discovered the remains of the Protestant Temple of Saint-Romain-de-Couzon, dating back to the 1630s and demolished immediately after the revocation of the Edict of Nantes (1685). After being studied by archaeologists, the vestiges are now integrated into the site.

Ehrmann's project obviously has a significant impact on the materiality and appearance of the built and natural components of the site. While many monumental sculptures and installations are located in the garden, colonizing the trees and what was once the pool, both the envelopes and the spaces of the buildings are transformed by adding or removing material, grafting of various objects from the recycling of industrial components, painting or burning of walls (Fig.2). The site's boundary wall, made of local stone, receives the same treatment. The roofs of the complex

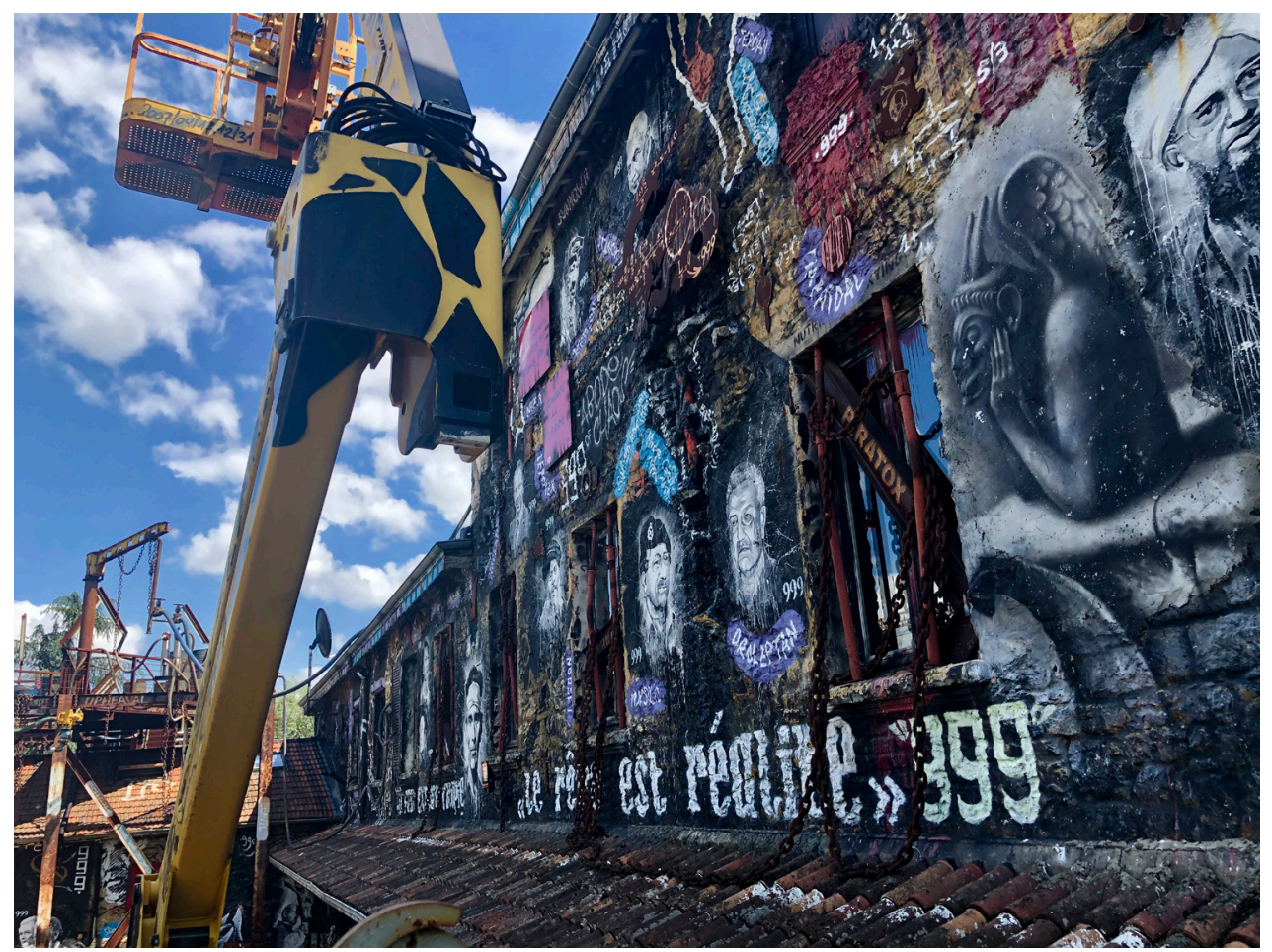

Fig.2 : Interventions in the buildings at the Abode of Chaos, @ thierry Ehrmann, 31.7.2019 (https:// www.flickr.com/photos/home_of_chaos/48705163927/in/album-72157709676617736/)

4 Ehrmann T., La Demeure du Chaos - The Abode of Chaos, Opus IX, Musée L'Organe, 2013. Available online : $\underline{\text { htps:// }}$ issuu.com/demeureduchaos/docs/demeureduchaos-abodeofchaos-opus-ix-1999-2013 
also host monumental installations, such as "Overground", built on the basis of a large piece of an oil platform. The Abode of Chaos is a living site in many ways : not only are the works of art that make it up constantly changing and evolving, but the buildings also house thierry Ehrmann's residence and the headquarters of his company Artprice, for which employees work on site every day, at the heart of the art project (Fig.3).

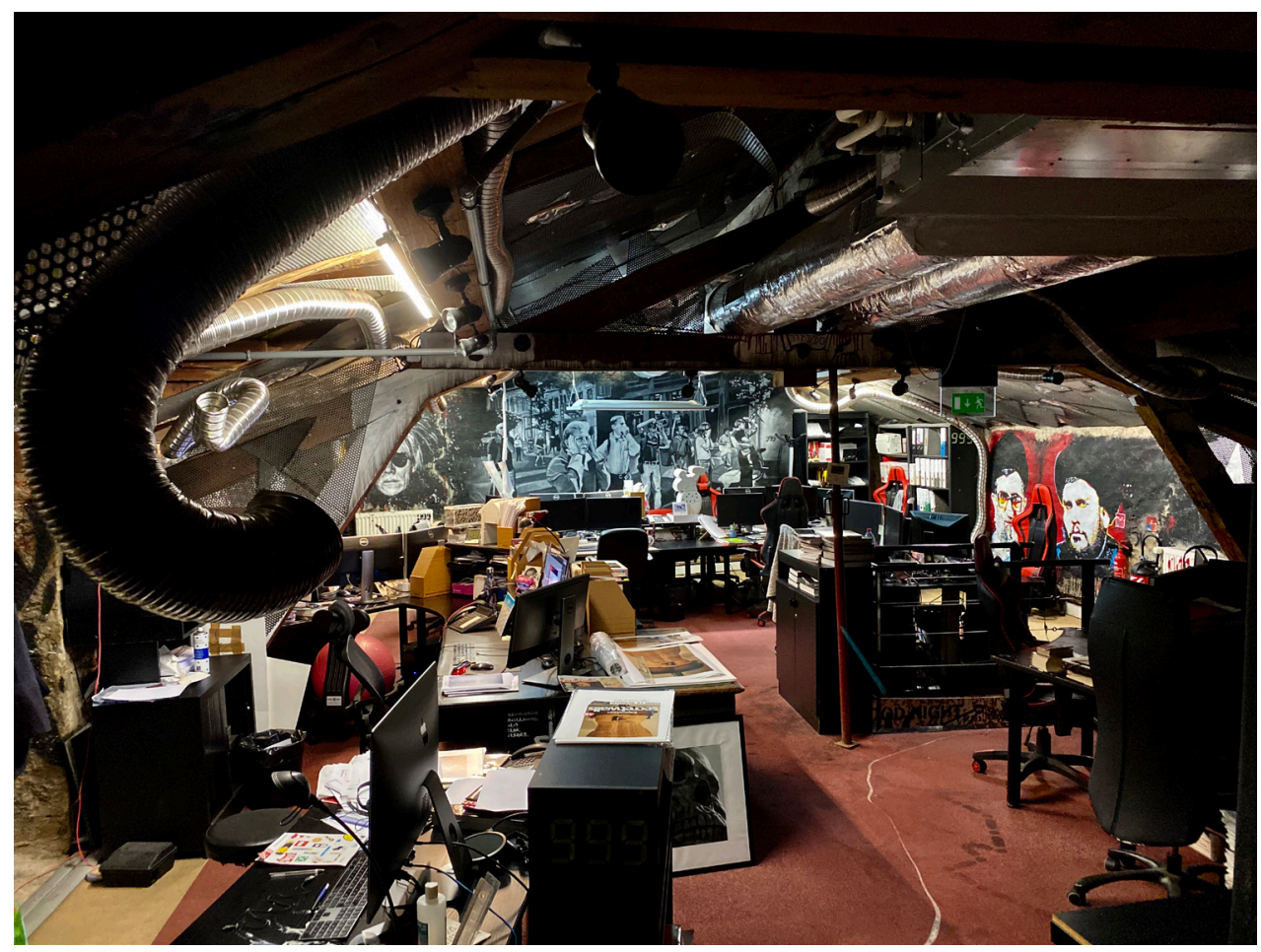

Fig.3 : The offices of Artprice at the Abode of Chaos (c) thierry Ehrmann, 9.11.2019 https://www.flickr. com/photos/home_of_chaos/49053235688/in/album-72157709676617736/

\section{Whose (disturbing) heritage?}

Although it expresses nothing more than what everyone observes from afar, every day, in the media - the condensed march of the world translated into space through art that can only be, like the news that feeds it, mostly chaotic and dark, it is disturbing. And it disturbs all the more through the contrast it creates with the apparently smooth and quiet environment of the well-todo suburbs. Despite the fact that most surrounding buildings are recent constructions covered with plasterwork that is only a distant reminder of the local "golden stone" (Fig. 4), since 2005, the authorities have required thierry Ehrmann to return the property to the state in which he found it. One of the most recent pieces of advice sent by the heritage administration in June 2020 states that "when it comes to intervening in old structures within the protected area, considered as 'ordinary' heritage elements constituting and enhancing the centre of the town, the principle of restoring the original layout, or respecting it, remains the main objective to ensure the best 
possible conservation conditions for this heritage"s. This is, of course, in total opposition to the artistic project of the Abode of Chaos, and only the tenacity of its owner and numerous legal actions to obtain justice have ensured that the site is still there today. However, its future remains uncertain.

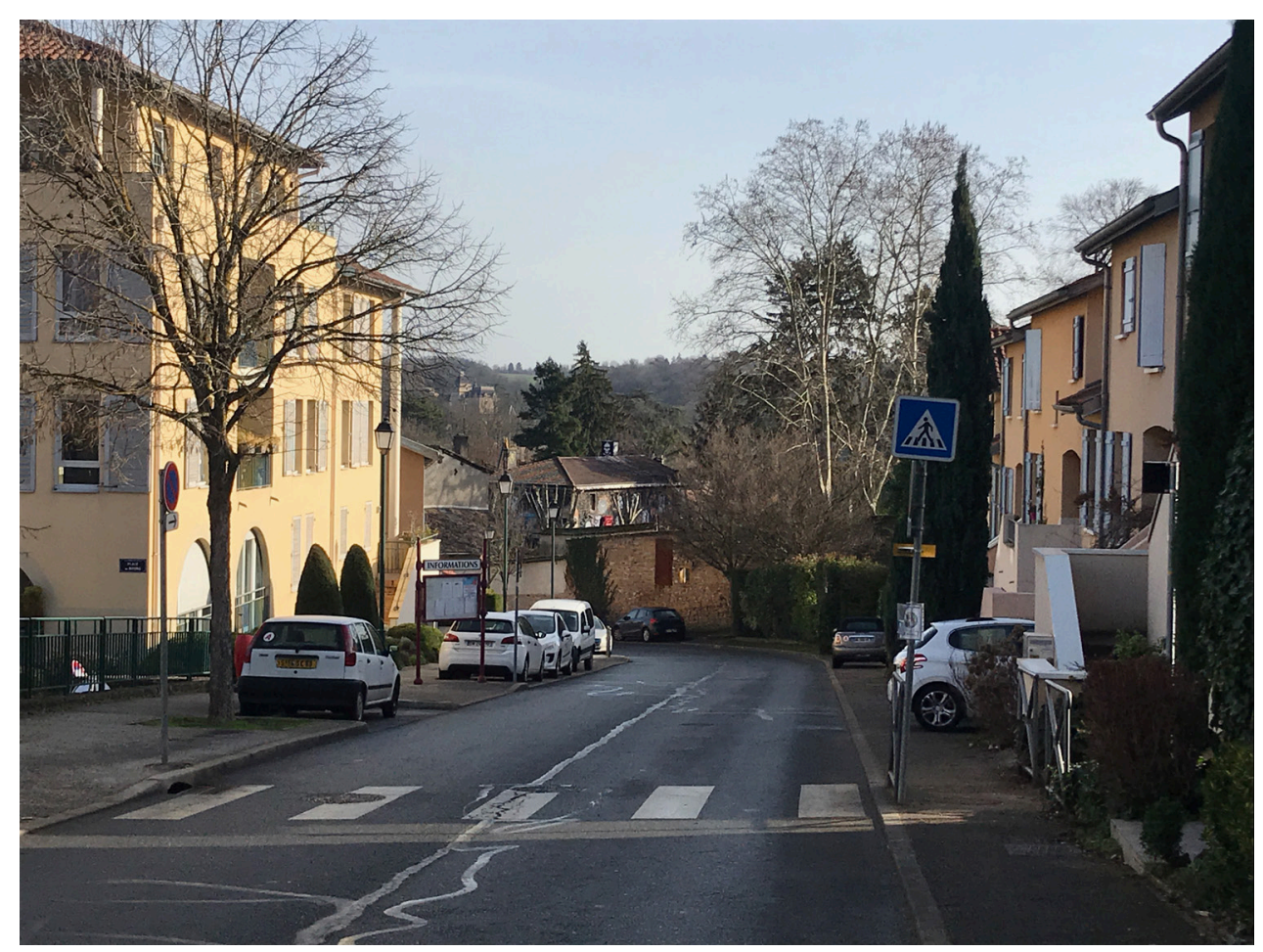

Fig.4 : The close environment of the Abode of Chaos () Author, 19.2.2021.

This story could remain an anecdote if the Abode of Chaos were not, by far, the most visited museum of contemporary art in the Lyon region, with more than 2000000 free visitors since 2006; an average of 180000 visitors per year and almost 4500000 followers on Facebook ${ }^{6}$. Outside the hushed circuit of art galleries, the site opens up to all types of audiences completely free of charge (Fig. 5); to date, about 770000 people coming from all continents and belonging to very varied socio-professional categories and cultural horizons (schools, institutions, medical centers, artists, protestant pilgrims, businessman, unemployed, retirees, associations, tourists, inhabitants of the village, etc.) have signed the petition to save it ${ }^{7}$. At the same time, many

5 Excerpt from a statement from the Regional Directorate of Cultural Affairs sent to the Abode of Chaos on 16 June 2020.

6 https://www.facebook.com/la.demeure.du.chaos.theabodeofchaos 999

7 Another petition, calling for the restoration of the site, received very anecdotal support (223 signatures). https://www. mesopinions.com/petition/justice/application-decision-justice-visant-remise-etat/205 
media around the world have devoted written, video or radio reports to this atypical site ${ }^{8}$. Thus, whether the experts like it or not, the Abode of Chaos is a part of the heritage of a very large, very diverse and very committed community. To date, however, it has not been possible to obtain any recognition of the cultural significance of the site from the local authorities or the French heritage institutions.

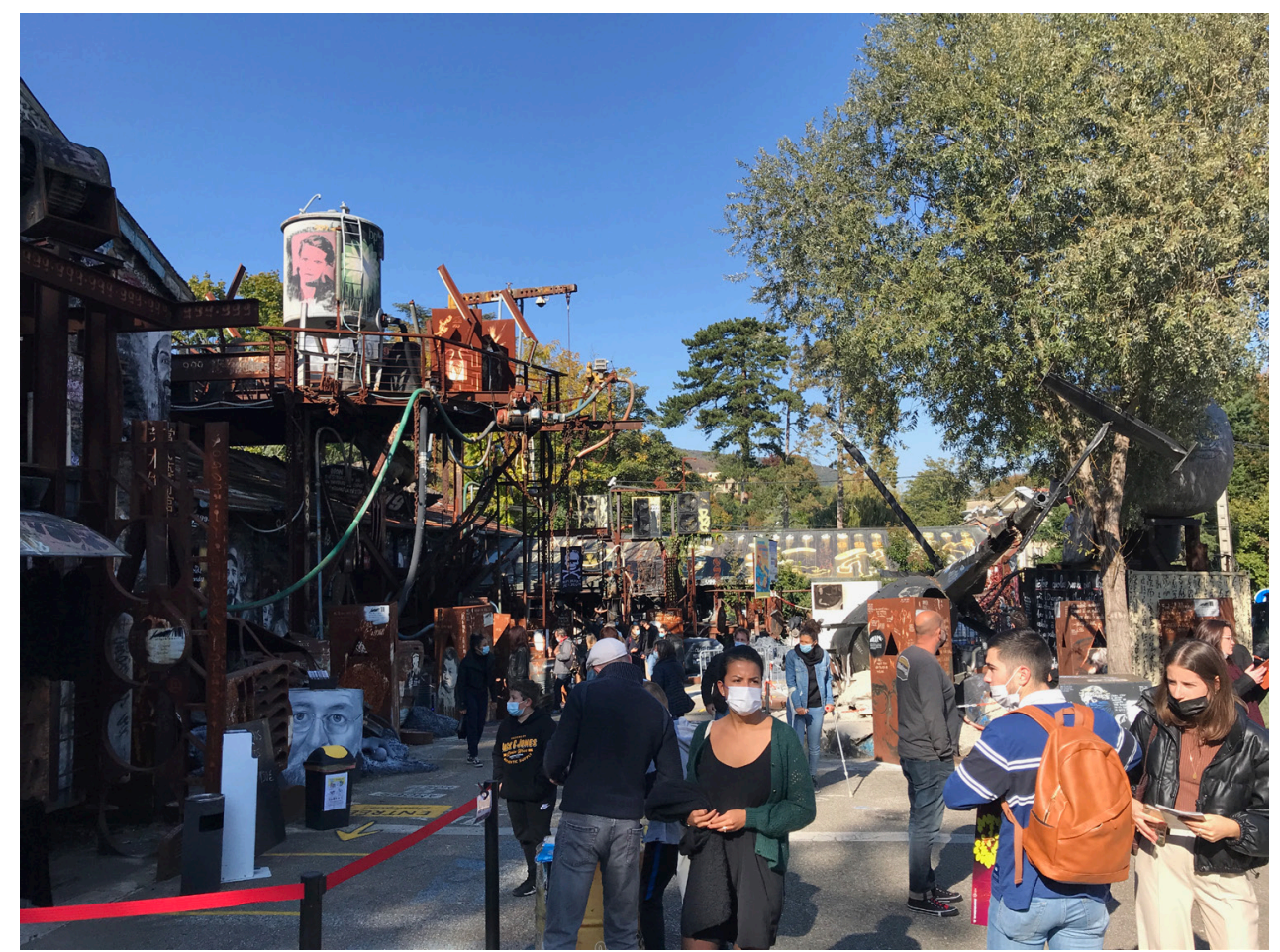

Fig.5 : Visitors at the Abode of Chaos during the National Architecture days (c) Author, 16.10.2021

\section{Assessing the cultural significance of the Abode of Chaos}

But what is this cultural significance? There are many resources available to answer this question. Some of these are provided by experts who have devoted architectural, historical or artistic studies to the Abode of Chaos. Among the most recent of these are the "Gesamtkunstwerk and singular architecture" study, directed by the SEMPER architectural office", and a historical study

8 For example : Leydier R., House Arrest, Art press, 353, 2009, p.5; Tagliabue J., It's His house. But, Village Traditionalists Ask, Is it Art? ?he New-York Times, July 19, 2006 ; Bouisset J., La Demeure du Chaos, prototype du musée de demain, L'Obs magazine, October 22, 2019; Tracksploration, Arte, 2018, https://www.youtube.com/watch?v=F1UtZJD8tQQ.

9 Detry N. (SEMPER Architecture), Rivière R. (agence AKHESEN), TT Geomètres Experts, La Demeure du chaos, Oeuvre d'Art Totale \& Architecture Singulière (The Abode of Chaos, Gesamtkunstwerk \& Singular Architecture), Saint-Romain-au-Mont-d'Or : Musée l'Organe, 2021. Available online : https://ftpl.serveur.com/abodeofchaos_ singular_architecture.pdf 
of the Protestant temple carried out by Raphaelle Rivière ${ }^{10}$, both in 2021. The numerous reports and press articles also reveal a variety of points of view about the place. But the most valuable source for perceiving the singularity of the site and understanding the attachment of very large public to it is undoubtedly the book "Honte à vous" (Shame on you), first published in 2008 and reprinted nine times since then, gathering 1827 comments written by signatories of the petition, from nearly 450 different professions ${ }^{11}$.

The study of these multiple resources, through the evaluation framework proposed in 2016 by L. Harald Fredheim and Manal Khalaf in their article "The significance of values: heritage value typologies re-examined"12, is particularly illuminating. The originality of this framework is to propose three successive stages in the evaluation process, aimed respectively at identifying what the heritage in question is ("features of significance"), the reasons why it is valuable ("aspects of value") and, finally, at qualifying of these aspects. This framework seemed to be particularly appropriate in the context of this very complex site since it limits the categories of values while being very comprehensive and inclusive. For the purposes of this article, we will limit ourselves to the aspects of the value of the site, i.e. the reasons why the public is attached to it.

Once the "features of significance" have been identified - which can be material ("forms") or immaterial ("relationships" and "practices") -, departing from the long lists of value typologies as produced by administrations or organisations in charge of heritage, Fredheim and Khalaf propose to limit the framework to four "aspects" of value: associative, sensory, evidentiary and functional. A study of the sources as mentioned above, focusing on explicit and implicit assessments produced by the experts and the public, reveals that all aspects are relevant. Yet, associative and sensory aspects are most mobilised in the public discourse.

\section{Associative aspects}

Under the term "associative aspects", Fredheim and Khalaf group all "those that express significant connections" with people, events, places, traditions, objects, etc., including fictional ones ${ }^{13}$. By its very nature as a "mirror of the Anthropocene", thierry Ehrmann's artistic project can only give rise to a multiplicity of associations that the public likes to decipher (without any caption, the site leaves a free interpretation of its contents to the visitors). Some of these associations are limited to a more informed audience, such as references to alchemy and chaos theory. Representative of the vernacular architecture of the region, the existing buildings also anchor the site in history and in local typologies; but in this respect, it is the remains of the Protestant temple and their necropolis that present the most interesting associative aspect. By recalling the consequences of

\footnotetext{
${ }^{10}$ Rivière R., La Demeure du Chaos Saint-Romain-au-Mont-d'Or, Etude historique du temple de Saint-Romain de Couzon, avril 2021 (unpublished).

${ }^{11}$ Honte à vous!, par les signataires de la Pétition pour sauver la Demeure du Chaos, 9th edition, Saint-Romain-au-Montd'Or : Musée L'Organe, 2018. The book is available online : http://blog.ehrmann.org/pdf/

${ }^{12}$ Fredheim L. H., Khalaf M., The significance of values: heritage value typologies re-examined, International Journal of Heritage Studies, 22, no. 6, 2 July 2016, pp. 466-481.

${ }^{13}$ Ibidem, p. 473.
} 
the revocation of the Edict of Nantes (1685), including the destruction of the temples, the massive exile of the Protestants and numerous massacres, the remains constitute a "difficult heritage" linked to a dark episode of history, just like those recounted by the Abode of Chaos (Fig. 6). The relationships between the different components of the site, as well as its relationship to the context, only reinforce these associative aspects of the value of the whole. Thus, the confrontation of the interventions with a simple vernacular building and its gardens, altogether banal and similar to so many others, makes the message of the artworks all the more percussive and disturbing, much more than if they had been conceived on a virgin ground or in an urban wasteland. The same can be said of the site's relationship to the residential housing developments that have gradually enveloped the site, especially since the late 1960s. The confrontation of the raw reality of the Abode of Chaos with the banality of a seemingly peaceful environment, where the darkness of the world is only observed through television screens, which can be turned off with a click of a remote control, makes its effect all the more powerful and meaningful. The interventions in the existing buildings, burned, scarified, covered with portraits and inscriptions, with the culminating "Overground", are impossible to ignore and arouse irrepressible associations with the violence which marked the 20th century and still marks our time.

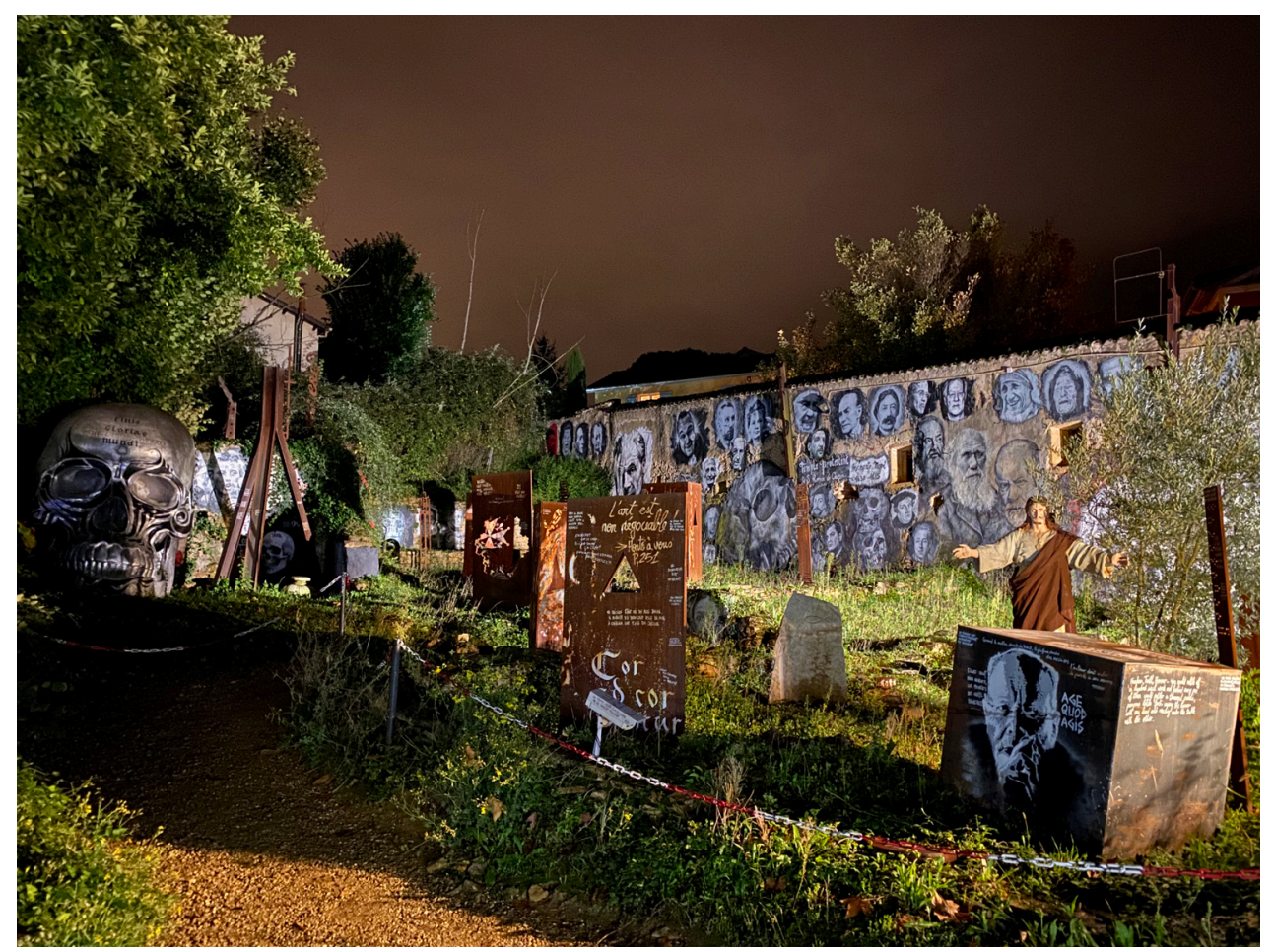

Fig.6 : The remains of the protestant temple, integrated into the project (c) thierry Ehrmann, 19.10.2019 (https://www.flickr.com/photos/home_of_chaos/48928732932/in/album-72157709676617736/)

For many signatories of the petition, the problems encountered by thierry Ehrmann for 15 years due to conservative town planning rules echo the famous scandals, such as the construction of the Eiffel Tower or Beaubourg in Paris, which aroused strong criticism before being fully 
integrated into the Parisian landscape and even representing the city by metonymy. Moreover, the narrowness of the point of view of the communal authorities, refusing to perceive the Abode of Chaos as a work of art in its own right, recalls famous trials, such as those of Whistler against Ruskin in 1878 or Brancusi against the USA in 1927, or dark concepts such as "degenerate art". Although relatively unclassifiable, thierry Ehrmann's creation process is regularly associated with those of other figures or artistic movements. The comparison with the "Ideal Palace" of the Postman Cheval is a recurring one from both experts and the general public. ${ }^{14}$. Like the Postman being famous today, but misunderstood during his lifetime, thierry Ehrmann builds a universe which is full of references, by using recycled materials. Kurt Schwitters' Merzbau is also a reference that is impossible to miss and, besides, claimed to share with the Abode of Chaos the same critical expression of the society's defects, by using its waste and invading right into the heart of the artist's intimate space. In addition to these recurring references, other comments collected in the book "Honte à vous" connect the Abode of Chaos with deconstructivism, art brut or pop art: just like Andy Warhol's Factory, the site welcomes other artists in a spirit of sharing and collective creation.

Finally, the practice of creative reuse, which is at the core of the Abode of Chaos, resonates with contemporary challenges in terms of the rational use of resources, reuse and recycling ${ }^{15}$.

\section{Sensory aspects}

In Fredheim and Khalaf's framework, the "sensory aspects of value" are the "sources of pleasure"16. After reading all the comments gathered in the book "Honte à vous", it appeared necessary to extend this criterion to "emotional aspects", as many comments insisted on this point, which had no place elsewhere in the evaluation framework used. Many of the adjectives used by visitors of the Abode of Chaos are indeed on the fringe of sensation and emotion: "beautiful", "fascinating", "sublime", "sensational", "masterful", "majestic", "spectacular", "pure and true", "grandiose". The site is also "surprising", "disturbing", "impactful", "troubling". It causes joy as well as sadness and makes one "shiver", "feel free", "chocked", "blown away", "turned inside out". The architectural wounds convey strong emotions related to a state of war, strongly contrasting with the apparently peaceful environment. The reused materials have a powerful expressive potential, aesthetically as well as emotionally. No one comes out untouched, especially since, unlike most museums, the public is free to wander through the works, to touch them and to confront them, which abolishes the distance between a visitor and the work. The Abode of Chaos is experienced rather than simply looked at or perceived.

\footnotetext{
${ }^{14}$ Rasle J., Le Roy E., Avec le Facteur Cheval, Paris : Musée de la Poste - Ecole nationale supérieure des Beaux-Arts, 2007, p. 18.

${ }^{15}$ Thierry Ehrmann's work is quoted in a seminal French book dealing with recycling in architecture : Huyghen J.-M., La poubelle et larchitecte. Vers le réemploi des matériaux, L’Impensé/Actes Sud, 2008, p. 54.

${ }_{16}$ Fredheim, Khalaf, op. cit., p. 473.
} 
From the sensory point of view, the relationship of the site with the village is controversial. On the one hand, the Abode of Chaos is visually integrated into the neighborhood by the size of its buildings and its enclosure walls, responding to traditional typologies. On the other hand, the artworks create a contrast of color and language, justifying the conflict with the City Council. Yet, if some of the site's detractors consider it simply "ugly", many contributions to the book "Honte à vous" emphasize, on the contrary, that, for some others, the Abode contributes to the "charm" of the village and helps to avoid monotony and standardization. Many also consider the ensemble to be much better integrated into its context than many recent residential or commercial developments, which, nevertheless, do not raise any protests.

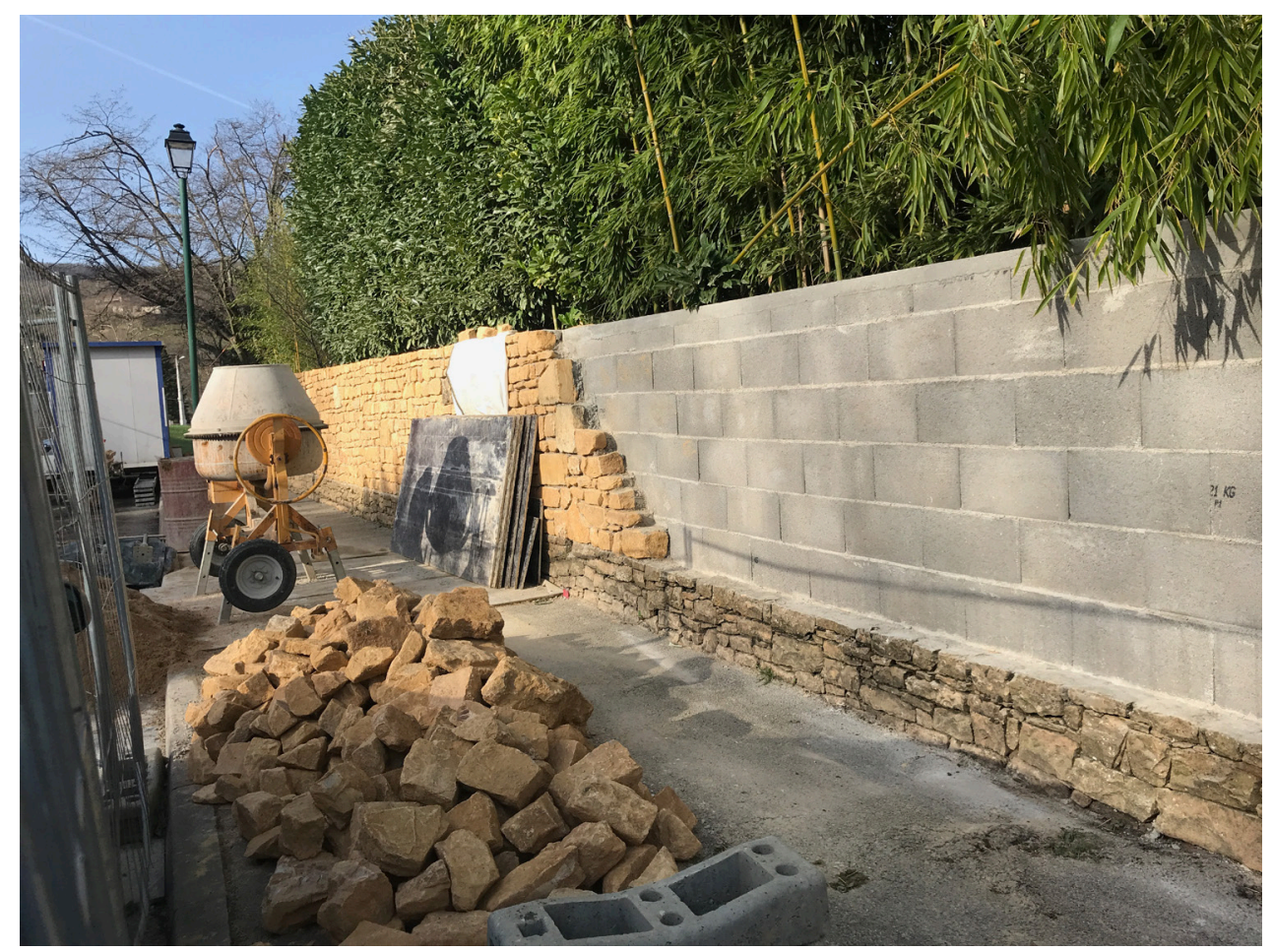

Fig. 7 : Construction of a concrete wall with a stone facing near the site, (C) Author, 19.2.2021

\section{A necessary dialogue}

When I first visited the Abode of Chaos, in February 2021, I parked my car in a street nearby lined with recent buildings adopting traditional profiles. Right next to my parking space, the municipality was building a wall of a "golden stone" facing a concrete structure (Fig. 7). A "facade integration" that is part of the same logic demanding that the Abode of Chaos regain its former appearance - that of ordinary but unnoticed vernacular buildings. Although I could not agree with this approach, I had to admit that it was very easy to find, among the many principles that we are constantly trying to formulate, disseminate and defend, many arguments 
to condemn the Abode of Chaos. And, as a corollary, it was very difficult to find arguments to defend it within the heritage world, at least from traditional perspectives.

Yet, if we accept that cultural significance is a social construction derived not only from experts carrying out an "authorized heritage discourse" ${ }^{17}$ validated by scientific arguments, but also from numerous users asserting their sensory and emotional expertise, and thus being agents rather than a passive audience ${ }^{18}$, the Abode of Chaos should undoubtedly join the multiform corpus of heritage. But if it finally does, what questions will it pose to our doctrinal principles and what will it bring to their development?

The Abode of Chaos is, of course, an "extreme specimen". But that makes it a particularly thoughtprovoking expression of the current questioning of European heritage practices inherited from the 19th and 20th centuries. It is becoming increasingly clear that these practices alone are no longer sustainable in the face of current challenges related to climate change, economic crises and diversification of actors involved in project making. The transmission process of increasingly diversified heritage, now encompassing a large part of the environment, far from the selective inventories of the mid-20th century, cannot be considered solely on the basis of concepts from the past. In the last ten years, this questioning has accelerated, notably with the foundation of the Association of Critical Heritage Studies in 2012 and the development of alternative approaches such as "post-preservation"19, "experimental preservation"20, "counterpreservation"21, "narrative approach"22 or "hardcore heritage" ${ }^{\text {"23 }}$. All these approaches call on the heritage world to open up to new open-ended perspectives, respecting the diversity of narratives carried by buildings or sites and the way they are experienced and interpreted by their current users, according to their contemporary questioning. In this sense, the Abode of Chaos shakes up reference points and principles questioning the way in which our relation to the past and to memory is materialized in our choices of intervention in the existing heritage, in the context of the current crises.

Among these recent reflections, the notion of "hardcore heritage" resonates particularly with the case of the Abode of Chaos. Defined jointly by the philosopher Erik Rietveld and the architect Ronald Rietveld, mainly active in the Netherlands, this approach conceives preservation "as an effort towards imagination and activation, rather than conservation". Rather than halting decay, it aims at "generating meaning" for the current and future generations. Through "strategic interventions" - like slicing in two a bunker being a part of the world heritage site of the "New Dutch waterline" (Fig. 8) - they aim at "providing affordances for spatial experiences that trigger one's imagination"24. Like thierry Ehrmann's Abode of Chaos, they accept that this creative

\footnotetext{
${ }^{17}$ Smith L., Uses of Heritage, Abingdon \& New York : Routledge, 2006.

${ }^{18}$ Smith L., Emotional Heritage. Visitor Engagement at Museums and Heritage Sites, Abingdon \& New York : Routledge, 2020, p. 14.

19 DeSilvey C., Curated Decay : Heritage Beyond Saving, Minneapolis : University of Minnesota Press, 2017.

${ }^{20}$ Otero-Pailos J., Langdalen E., Arrhenius Th. (ed.), Experimental Preservation, Lars Müller Publishers, 2016.

${ }^{21}$ Sandler D., Counterpreservation. Architectural Decay in Berlin since 1989, Cornell University Press, 2016.

22 Walter N., Narrative Theory in Conservation, Abingdon \& New York: Routledge, 2020.

${ }^{23}$ Rietveld E. , Rietveld R., Hardcore Heritage: Imagination for Preservation, Frontiers in Psychology, 8, 2017, art. 1995 (available online : https://www.frontiersin.org/articles/10.3389/fpsyg.2017.01995/full)

${ }^{24}$ Ibid., p. 1.
} 


\section{Claudine Houbart}

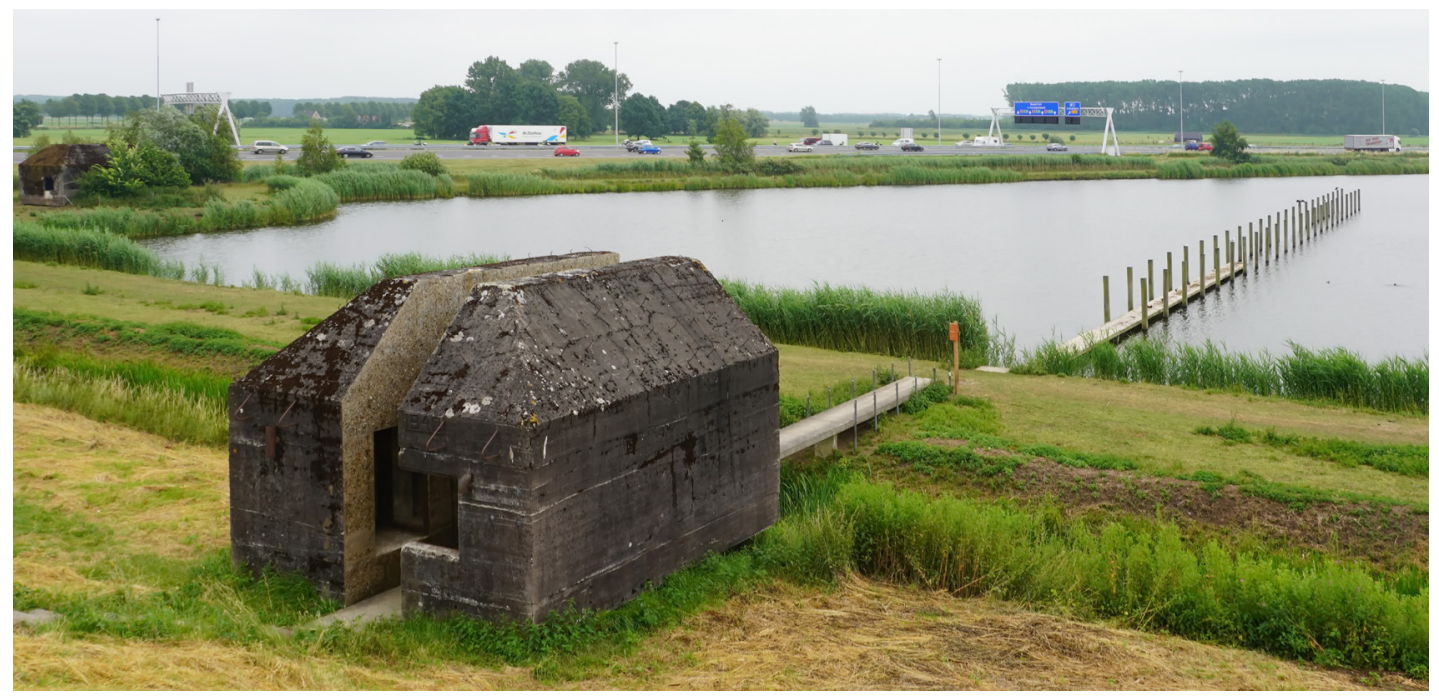

Fig. 8 : RAAAF \& Atelier de Lyon, Bunker 599, Culemborg (NL), 2010 @ Bertknot, Creative Commons, 20.6.2018

approach may lead to destructions, disturbing additions or radical changes in order to create tensions or new dynamics. Just like the sliced bunker sheds light on all the not-sliced ones' cultural significance ${ }^{25}$, the continuous transformation of the architectural substrate of the Abode of Chaos sheds a different light on its direct environment, but also on the way we consume and live at a distance from world events. But unlike "Bunker 599", which became a national heritage site following the intervention, the Abode of Chaos has so far received no recognition from the authorities and its very existence is still under threat.

As an extreme case, the Abode of Chaos illustrates the gap that can exist between doctrinal documents and alternative approaches, which are currently flourishing, often legitimized by massive user support. It suggests to us that, ninety years after the Athens congress, we do not only have the task of sorting out our numerous and sometimes contradictory doctrinal documents. We should also ask ourselves how to dialogue constructively with these new approaches so that heritage continues to appeal to its multiple audiences and so that conservation indeed strikes the right balance between stakeholder and heritage rights.

${ }_{25}$ Rietveld E., Rietveld R., Mackic A., Strategic Interventions as a Design Approach, [in:] Vacancy studies : experiments \& strategic interventions in architecture $=$ experimenten \& strategische interventies in architectuur, Amsterdam : nai010 publishers, p. 86 (available online : https://dare.uva.nl/search?identifier=9b27d3f0-422e-4f92-9ce8-072aclcf4ea7) 